\title{
Vaderskap in die Pauliniese korpus volgens 1 Korintiërs
}

\author{
F S Malan ${ }^{1}$ \\ Navorsingsassosiaat: Departement Nuwe-Testamentiese Wetenskap \\ Universiteit van Pretoria
}

\begin{abstract}
Fatherhood in the Pauline corpus according to 1 Corinthians

The word pathr appears five times in 1 Corinthians: three times referring to God (1:3; 8:6; 15:24), once to Paul (4:15), once to Israel in the desert (10:1), and once to a physical father (5:1). Paul's idea of fatherhood are his Jewish background, his view of the Greek and Roman conception of fatherhood, and his interpretation of the Old Testament understanding thereof. These images and Paul's subtle differences from them are explored. Paul's idea of fatherhood arises from his faith in God's relationship with Jesus, and, through the crucified and risen Christ, with the congregation and the whole creation. Paul's own humble life portrays Christ's humiliation and the Father's grace.
\end{abstract}

\section{INLEIDING}

Die woord pat hr kom ses maal in 1 Korintiërs voor: drie maal van God as Vader:

1 a p 0 ;qeou'pat r $0 ;$ hfnwh̀ in die seëngroet (1:3),

2 eif qeo $\sim$ oJpat hr in die geloofskennis (8:6),

3 in die eindverwagting wanneer Christus die koningskap t w/ gew/ kai; p a t ri voordra (15:24).

4 ouj pollour patera $\sim$ in 4:15 verwys na Paulus as die geestelike vader van die gemeente en van Timoteus in 4:17;

5 gunaika ... t ou'pat $r 0 ;$ in 5:1 verwys na 'n lidmaat wat die vrou van sy vader het;

\footnotetext{
${ }^{1}$ Prof F S Malan (emeritus-professor van die Universiteit van die Noorde) is ' $n$ lid van die navorsingseenheid van die Department Nuwe-Testamentiese Wetenskap, Fakulteit Teologie, Universiteit van Pretoria, onder leiding van prof dr J G van der Watt.
} 
6 oijpat eve hmwn' in 10:1 verwys na die Israeliete in die woestyn as vaders van die gelowiges.

Daarby laat Paulus 'n paar maal in die brief sy standpunt oor die posisie van die man blyk. Hy skryf ook die hele brief as die gemeente se geestelike vader. Vanuit sy verhouding met Christus Jesus gee Paulus blyke in 1 Korintiërs dat sy siening van vaderskap tog verskil van die gangbare beskouings van sy tyd. Dié subtiele verskille sowel as wat Paulus se mening oor vaderskap beïnvloed het, word van naderby beskou.

Die antieke Griekse stamme en state het feitlik almal die voogdyskap van die man oor sy vrou en kinders erken, en Zeus is as vader aangeroep (Hom I/ 1:544, 3:365; Epict, Diss 1:19:12). By die Romeine is die man se patria potestas in hulle wette vasgelê (Gaius, Inst 1:18-90) en Jupiter is die Latyn vir Z eu $\forall$ p a t hr. Die Joodse siening was ook paternalisties ${ }^{2}$ met die vrou en kinders onder die gesag van die man (SB I:706), en in die eerste eeu voor Christus word God al meer as Vader in die sinagoges aangespreek (vgl Schrenk 1954:978; en aanhalings in SB I:392-393).

Paulus se siening van vaderskap in 1 Korintiërs impliseer sy opvatting vanuit sy Joodse agtergrond, sy idee oor wat die Grieke en Romeine van vaderskap dink, sy siening van wat die Ou-Testamentiese skrywers daarvan gedink het, maar word gevorm deur sy geloof in God se verhouding tot Jesus, en deur Jesus tot die gemeente en tot die hele skepping.

\section{DIE POSISIE VAN DIE FISIEKE VADER EN MAN (5:1-5; 7:2-4; 11:2-16; 14:34-36?)}

\subsection{Vaderskap onteer (5:1-5)}

Hierdie perikoop handel eintlik oor die gemeente se optrede of gebrek daaraan, en Paulus se opdrag aan hulle om teen die oortreder op te tree. Dit raak egter Paulus se siening van vaderskap aan en gee moontlik 'n aanduiding van die bronne van sy denke daaroor. Hy verwys ook na "die heidene" ( $t$ a ; eqgh ) se beskouing. Die brief word in Grieks aan Grieke geskryf en die Hellenistiese denke daaroor word waarskynlik by "die heidene" betrek. Korinte is egter vir meer as twee eeue (vanaf $146 \mathrm{vC}$ tot ongeveer $55 \mathrm{nC}$, toe die brief geskryf is) onder Romeinse bewind, en betrek ook die Romeinse reg en opvatting oor vaderskap.

\footnotetext{
${ }^{2}$ Die woord paternalisme het 'n negatiewe klank gekry. Dit het 'n vader (pater) beskryf wat sy kinders met liefde versorg. Nou klink dit meer na 'n onsensitiewe stiefpa wat uit sy gesagsposisie afbuig om sy afhanklikes te help. Sonder liefde word selfs goedbedoelde hulp 'n belediging. Paulus het God egter leer ken as ons Vader wat uit louter genade gee wat ons nie verdien of voor gewerk het nie (vgl Yancey 2002:155-157).
} 
Die Korintiërs is nie bedroef oor 'n geval van bloedskande in hulle midde nie. Paulus verwyt hulle dat hulle hoogmoedig is oor hulle gewaande geestelikheid, sonder om aandag te gee aan 'n sedelike vergryp in die gemeente (5:2; dit is onwaarskynlik dat hulle oor die spesifieke geval trots is as 'n voorbeeld van hulle nuwe vryheid in Christus (contra Barrett 1971:122; Fee 1993:202). Paulus beskryf bloedskande as onsedelikheid van so 'n aard as wat selfs onder die heidene nie voorkom of geoorloof is nie (Dié Griekse sin het nie ' $n$ werkwoord nie). 'n Lidmaat van die gemeente leef in 'n seksuele verhouding met sy stiefmoeder, gunh vt ou'p at r $0 ; \sim$ ek ein (5:1). Paulus beskou die skending van die vader se eer ook as ondermyning van die gemeente se naam voor die heidene wat so 'n geval veroordeel. In plaas van hoogmoed, moet die gemeente eerder die aantasting van 'n vader se eer as sonde beskou en daaroor treur (5:2, vgl 4:6).

\section{2 'n Aanduiding van die bron van Paulus se denke}

Paulus gebruik dieselfde term as die Septuaginta se vertaling van אָׁשֶת אָרביו in Levitikus 18:8,11; 20:11 en Deuteronomium 22:30 (23:1); 27:20. Nadat Levitikus 18:7 omgang met jou moeder verbied (die LXX vertaal ma emet mhthr), verbied Levitikus 18:8 omgang met die vrou van jou pa (die LXX vertaal die Hebreeus letterlik ... guna iko $\sim$ pat r $0 \nvdash$ s ou), wat dan duidelik na die stiefmoeder verwys (die Griekse term vir 'n stiefmoeder is egter mh t r ui a v en mht r ui og a mo vir iemand wat met sy stiefmoeder trou). Die gebruik van die Septuaginta se term versterk die moontlikheid dat Paulus die LXX gebruik, en in hierdie geval ook die Ou Testament se standpunt oor bloedskande volg. Terwyl die Egiptenaars en Kanaäniete ("heidene") dit skynbaar toelaat (Lev 18:3), bring so 'n verhouding volgens Levitikus skande oor die pa van 'n Israeliet, en beide die man en sy stiefmoeder moet doodgemaak word (Lev $18: 24,30 ; 20: 11$ ). Dit is 'n skande wat die Here verafsku (ebdel uxa mhn, Lev 20:23) en Hy is Israel se bron en maatstaf vir die lewe (Lev 18:1-5).

Deuteronomium 27:20 plaas 'n vloek op die oortreder waarop die volk hom met hulle "amen" uitwerp (vgl von Rad 1966:167). Die rede "omdat hy sy pa se bedekking (s ug ka Vumma) ontbloot het" verwys na seksuele omgang en beklemtoon die man se minagting van sy pa.

Dieselfde soort distansiëring van die oortreder waarna Deuteronomium verwys, word deur Paulus as die Korintiërs se geestelike vader (vgl punt 2 hieronder) aan die gemeente opgedra. Maar Paulus kwalifiseer die "oorgee aan die Satan" met 'n uitsig en 'n beperking: die sensuur deur die gemeente geskied in die gesindheid en onder die leiding en werksaamheid van die Here Jesus wat in die Gees by hulle teenwoordig is, met die doel (i i i a ) dat die oortreder gered sal word op die dag wanneer die Here kom (5:3-5). Vanuit die liefdesoffer van Christus wat as ons paaslam geslag is, is daar vergiffenis vir 
sondaars (5:7). Die Korintiërs word opgeroep om fees te vier sonder die ou suurdeeg, wat volgens 5:6 verwys na hulle roem ten spyte van bloedskande in hulle midde (5:8).

Die verwerping deur die gemeente onder leiding van Christus skep die verwagting van die sondaar se redding op die oordeelsdag. Vir Paulus is die eer teenoor die vader egter so belangrik dat Deuteronomium aangehaal word: "verwyder die slegte mens onder julle uit" (5:13; in Deut 22:21 deur die steniging vir owerspel). Paulus handhaaf die gesag en eer van die vader, maar vanuit die verlossing wat God deur Christus bewerk het, skep hy ruimte vir die redding van die sondaar.

\subsection{Die Ou-Testamentiese siening van die vader}

Die Ou-Testamentiese afwysing van dié tipe bloedskande vloei voort uit die vyfde gebod (Eks 20:12). Die Here skenk die lewe deur vader en moeder. Terwyl die eerste gebod die verhouding tot die Here uitspel as die begin van sy verbond met ons, is die verhouding tot vader en moeder die begin van die kind se lewe in die verbondsgemeenskap. Dit is die beginpunt vir elke menslike verhouding en staan daarom aan die begin van die tweede tafel van die wet. Daarom moet ouers hoog geag en bemin word vir die voorrang wat die Here aan hulle gee (vgl Durham 1987:290-291).

Om gemeenskap met die vrou van jou pa te hê, bewys jou minagting vir jou pa deur wie God die lewe aan jou gegee het. Vaderskap vra juis respek en liefde vir die persoon deur wie God lewe aan jou gegee het, en daarmee saam jou waardeskatting van jou eie lewe, van jou gemeenskap, van die mensdom en van God. Jakob het 'n vloek uitgespreek oor sy oudste seun Reuben wat die heiligheid van sy bed geskend het, en hy het daarom sy voorrang verloor as die eersgeborene wat aan God gewy is (Gen 49:3-4; 35:22; vgl Absalom in 2 Sam 16:21-22).

Paulus sluit waarskynlik by die Ou Testament aan en beskou die optrede van die man as inbreuk op die posisie van die vader, as skending van die eerbied vir hom deur wie God die lewe aan jou gegee het, en so van jou eie lewe en van die eer van God (vgl Gen 9:22).

Uit 1 Korintiërs 6:16 blyk dit dat Paulus op grond van Genesis 2:24 seksuele omgang beskou as die liggaamlike vereniging van twee persone. Daarom sou die vrou van jou vader beskou word as die persoon wat liggaamlik met die vader verenig is, en omgang met haar eintlik die verkragting van die vader se liggaam insluit. Uit 6:19-20 blyk Paulus se hoogagting van die liggaam as tempel van die Heilige Gees, teenoor die Grieke se geringskatting daarvan as kerker van die siel (vgl Plato se aanhaling van die Orfiese digters t 0; s w ma veśt in s h ma t hi y uch $\sim$, Gorg 493a; Crat 400b,c). Dieselfde beskouing heers nog in Paulus se tyd (vgl 
s wmat i sundedememo , pros dedes qa i t w/s wmat $i$, in Epict, Dis $1: 1: 9,14-15)$.

\subsection{Grieks-Romeinse beskouing oor die vader/man}

Toe die Grieke nog in klein stadstaatjies (p ovei ) gewoon het, was die vader van elke huis (oiko ) met sy plasie, die voog (kuri $0 \sim$ ) oor sy vrou, kinders, skoondogters en kleinkinders. Na die Persiese en Peloponnesiese oorloë, die verspreiding van die Hellenisme na Alexander se wêreldoorheersing, en die Grieke se oorgawe aan die Romeine in $146 \mathrm{vC}$, het die gesinslewe baie verander. Vaders was lang tye weg op kommando, en die vroue moes die gesin versorg. Na die oorloë is baie slawe huis toe gebring. Die ekonomie het begin floreer. Dorpe het versterkte stede geword. Egskeidings het algemeen geword. Die gesag van die vader het heelwat verander en die Hellenistiese tydperk sluit af met die Griekse koningin Cleopatra VII op die troon van Egipte vanaf 51-30 vC (vgl Fantham e a 1994:136,140).

Plato (428-348 vC) het 'n staat propageer waarin vroue ook voogde sou wees, met gelyke regte as die man (Leg 3:690a). Aristoteles (384-322 vC) verskil van sy leermeester. Hy glo vroue verskil wesenlik van mans ten opsigte van hulle geestelike eienskappe en maatskaplike bevoegdheid ( $P o l$ 1:2:19-21; 5:1-2; vgl Blundell 1995:184-187). Epictetus (50-120 nC, Diss) vermaan seuns om in alles aan hulle vader gehoorsaam te wees (2.10.7) en selfs wanneer hulle geregverdig sou wees nie op te hou om hulle vader te eer nie (3:11:5). Hy beskryf die "vader" in die vader as die man wat sy gesin innig liefhet ( $f$ il os t or g o b), die sagte minsame man in hom (h fner $0 \sim ; 3: 18: 5$ ). Aan die vader het God onder andere sy kinders en sy vrou onderwerp (up ot a s S W, 4:1:100), ook om hulle te beskerm (p r o i st a meno , 3:24:3). Hy weet egter dat vaders ook onredelik kan wees (a g nwmwn, 3:21:5), met harde harte (c a l ep o 4 4:1:43).

Die antieke Romeinse samelewing was gebou rondom die pater familias en patria potestas. Dit verwys na die man se gesag in die huisgesin oor sy vrou, kinders, skoondogters, kleinkinders, afhanklikes en slawe, en hulle wetlike onderdanigheid aan hom as die priester in die huis. Cicero (106$43 \mathrm{vC}$ ) het egter reeds aangedui dat vaderlike gesag weldadig was en geredelik aanvaar is (Rep 3.25) en Plutarchus (50-120 nC) sê die waardevolste en heiligste vir die man is sy vrou en kinders (Cato Maior 20.2; vgl Saller 1998:86-91). Voor die slag van Actium in 31 vC verklaar Octavianus voor sy leërs dat geen vrou toegelaat sal word om haarself aan 'n man gelyk te stel nie (Dio C HR 50.18.3).

Schrenck meen dat die uitwerking van die Romeinse beskouings op die Griekse reg en op Joodse ouers met Romeinse burgerskap in die eerste eeu na Christus duidelik is (1954:950-951 ). Mitteis het egter reeds in 1891 
aangetoon dat die lokale reg in die Oostelike deel van die ryk in die eerste eeu nog in volle gang was en selfs die Romeinse denke en uitoefening van die reg beïnvloed het (1963:109-110). Die Grieke het nie die vaderlike gesag oor die familie in die Romeinse sin geken nie, maar wel die voogdyskap van die man oor sy vrou, wat na sy dood op sy seun oorgaan. Dit het aan die vrou groter vryheid gegee as in die Romeinse reg (vgl die bespreking van die verskillende stamme se reg in Mitteis 1963:63-66). Maar in sowel die Romeinse reg as die Griekse burgerlike reg verhinder bloedverwantskap 'n huwelik van 'n man met sy vader se vrou (vgl Mitteis 1963:105).

$\mathrm{Na}$ die vaders se afwesigheid as soldate in die Puniese, Oosterse en Europese oorloë het vaderskap in die Romeinse ryk egter baie krag verloor en het egskeiding en buite-huwelikse verhoudings floreer (Seneca, $4 \mathrm{vC}-65 \mathrm{nC}$, Ben 3:16:2). Om die huwelik te red, die morele lewe te verbeter en genoeg burgers vir die ryk te kweek het Augustus in $18 \mathrm{vC}$ die Lex Julia de maritandis ordinibus en die Lex lulia de adulteriis deur die Senaat gevoer, en in $9 \mathrm{nC}$ die Lex Papia Poppaea. Daarin word die vader se beheer oor huwelike verslap (vgl Fantham e a 1994:305; Csillag 1976:30-35; 70-74; Ortolan 1896:243248).

Terwyl onsedelikheid (p or nei a) in die Grieks-Romeinse samelewing oorgesien is, is bloedskande verafsku vanuit hulle opvatting oor die eer van die vader (vgl Findlay 1951:807). Cicero beskou bv. die huwelik van Sassia met haar skoonseun Melinus as 'n ongehoorde misdaad (scelus incredibile, Pro Cluenti 5\&6). Martialis skryf in $88 \mathrm{nC}$ 'n epigram om Gallus te beskuldig dat hy met sy stiefma gelol het en na sy pa se dood saam met haar gaan woon het (Epigrammae 4:16). Tacitus (54-117 n Chr) vertel hoe Sextus Marius van Spanje deur Tiberius in Rome tereggestel is op die aanklag van bloedskande (defertur incestasse filiam, Ann 6.19).

\subsection{Die Joodse beskouing oor die vader/man}

Vader en moeder moet beide geëer word ( $v g l$ Sir 7:27; 23:14; Tob 4:3-5) maar die vrou staan onder die gesag van haar man (TQid 1:11(336) in SB I:706). Philo (20 vC-50 nC), onder invloed van die Griekse reg, verteenwoordig die streng patriargale standpunt (Spec Leg 2:293ff; Schrenk 1954:974:22-24). Josefus (37-97 nC) sê: "Die wet sê die vrou is in alles onder die man se mag (c eirwn). Daarom moet sy gehoorsaam wees aan hom, nie om misbruik te word nie (mh; p r $0 ; \sim$ u $(\mathrm{r}$ in), maar dat sy gelei kan word, want God het die gesag aan die man gegee" (Ap 2:201:25).

Billerbeck is redelik seker dat die meeste Joodse geleerdes, wat dit vir Jode verbied, in die tyd van die Nuwe Testament niks teen 'n huwelik van 'n proseliet met sy stiefmoeder gehad het nie, en dat hulle verslapping van die eis vir proseliete die Christengemeentes beïnvloed het. Hy verwys na rabbi Eliëser wat teen $90 \mathrm{nC}$ die huwelik van 'n proseliet met sy stiefmoeder toelaat, 
en sy standpunt sou seëvier ten spyte van rabbi Aqiba (sterfdatum $135 \mathrm{nC}$ ) se verbod ook vir proseliete (SB 3:346, 356 n 1, 358). Maar die Joodse skrywers laat niks daarvan blyk nie. Schrage (1991:370) meen dat Billerbeck die situasie in Korinte verkeerd interpreteer.

In so 'n samelewing van Romeine, Grieke en Jode moet Paulus sy siening van vaderskap uitwerk, veral vanuit sy vertroudheid met die Ou Testament en sy nuwe insigte vanuit sy lewe in gemeenskap met Christus.

\subsection{Man en vrou as gelykes (1 Kor 7)}

Teenoor die Romeinse patria potestas, die Griekse en Joodse paternalistiese tradisie, spreek Paulus in hoofstuk 7 telkens man én vrou aan sonder enige teken van onderwerping van die vrou aan die man se gesag (7:2-5, 8-9, 10 $11,12-16,28,32-34)$. Paulus se merkwaardige argument in 7:4 stel die vrou net soveel in beheer oor haar man se liggaam as die man oor haar liggaam (vgl Gal 3:28: in Christus Jesus is julle almal - man en vrou - één).

\subsection{Man en vrou as onderskeie geslagte (1 Kor 11:2-16)}

In 11:2-16 gebruik Paulus 'n paar argumente om te motiveer waarom 'n vrou se kop in die erediens bedek moet wees (kat a ka l up t ein, Schrage 1995:507-509 meen dit beteken: met versorgde opgebinde hare) om die onderskeid wat God tussen manlik en vroulik gestel het te eerbiedig. Benewens die verwysing na die skepping in verse 8-9 is die argumente in verse 4-6 en 13-16 rondom die bedekking van die kop al dan nie, kultuurgebonde (vgl Malan 1985).

In die argumente gaan dit egter nie oor die onderwerping van die vrou aan die man soos in die patriargale kultuur nie, maar primêr oor die kerkdrag van mans en vroue om die onderskeid van die geslagte aan te dui, hoewel die kef a I h vanalogie $^{3}$ duidelik 'n voorrang aan die man bo die vrou gee. In vers 3 word voorrang toegeken in die orde: God - Christus - man - vrou. Terwyl Christus die hoof is van die man, moet die man met onbedekte kop in die erediens optree, as die beeld en heerlikheid van God. Die vrou moet met 'n bedekte kop in die erediens optree want sy is die heerlikheid van haar man (11:7; LXX Spr 11:16 gunh; euraris t o ej ei vei a judri; doxan, vgl 1 Esdr $4: 17)$ wat nie in die erediens vereer word nie, want hier word God vereer.

In verse 4-5 aanvaar Paulus dat beide man en vrou die reg het om in die gemeente te bid en God se boodskap te verkondig. In verse 11-12 wys hy daarop dat man en vrou heeltemal van mekaar afhanklik is in die nuwe bedeling van die Here (ej kuri w) en dat die onderlinge afhanklikheid van man en vrou die wil van God is ( $a ; d e ; p$ a mt a ek t ou 'qeou). Dit stem

\footnotetext{
${ }^{3}$ Oor die gesprek tussen Grudem en Fitzmeyr aan die een kant, wat kef al h vas 'n aanduiding van gesag oor ander beskou, met Bedale en ander, wat kef a I h vas bron of begin beskou (vgl Perriman 1994:602-619; vgl Horrell 1995:171 oor die betekenis van kef al h vas voorrang).
} 
ooreen met hoofstuk 7 waarin 'n patriargale houding teenoor die vrou duidelik nie bevorder word nie; en dit stem ooreen met die Ou-Testamentiese wet wat eer vra vir vader én moeder deur wie die Here die lewe aan jou geskenk het (Eks 20:12).

Die tipiese patriargale posisie van die man kom wel in 1 Korintiërs 14:34-35 na vore, maar die verse is waarskynlik 'n vroeë kanttekening vanuit 1 Timoteus 2:11-14, wat in stryd is met Paulus se siening in die res van 1 Korintiërs (Schrage 1988:224; vgl die argumentasie in Fee 1993:699-705; Horrell 1995:184-195).

\section{DIE GEESTELIKE VADERSKAP VAN DIE GEMEENTE SE STIGTER}

Paulus sluit sy lang argument (1 Kor 10-4:21) oor die gemeente se groeiende verset teen hom en sy evangelie af met 'n beroep op sy geestelike vaderskap van die gemeente. In gemeenskap met Christus Jesus het hy die goeie boodskap aan hulle verkondig en so die vader geword wat die gemeente verwek het (ejg w; unna 〜 ej ennhs a, 1 Kor 4:15). Die inhoud van sy boodskap is Jesus as die Christus wat gekruisig is, gesterf het en opgewek is vir ons sondes (2:2; 15:1, 3-4). Dít alleen is die fondament van Paulus se vaderskap. Sy vaderskap word bewerk deur die evangelie wat hy verkondig. Dit is eintlik 'n afgeleide vaderskap. God is die eintlike Vader wat die gemeente vir God afgesonder en geroep het (1:2; vgl Deut 32:18). Dit het God gedoen deur Christus Jesus $(1: 2 ; 4: 15)$. Paulus het die fondament van die gemeente gelê (3:10) en ander, leermeesters (4:15), bou daarop. Die fondament is Jesus Christus (3:11). Tog bly Paulus die vader met die gesag oor, versorging en verantwoordelikheid vir die gemeente, en die ander bouers moet mooi kyk hoe hulle op die fondament voortbou (3:10).

Paulus is voortgaande besig om sy geliefde kinders te onderrig in die regte gedrag en geloof (nouget w praesens 4:14). As 'n wyse vader doen hy 'n ernstige beroep op hulle ( $p$ a r a ka I w) om deurentyd hulle stigter se gedrag en geloof na te volg (mi mht a i vmou gi mes qe 4:16). Hy het juis sy geliefde vertroubare geestelike kind Timoteus gestuur om hulle te herinner aan sy lewenswyse en leer (oflou $\forall$ meervoud) wat hy in gemeenskap met Christus oral in elke gemeente voorgeleef en geleer het (4:17). Teenoor hulle hovaardige "geestelikheid," "wysheid" en Hellenistiese dualisme wat die materiële en liggaamlike gering ag, stel Paulus sy voorbeeld van nederige diens en uitlewing van sy geloof in die gekruisigde Christus (1:23; $2: 2)$. In 4:813 beskryf Paulus sy eie lewe van ontberings en vernederings as verteenwoordiger van Christus teenoor die Korintiese ambisies oor grootheid en wysheid. In 2:1-5 beskryf hy sy eie swakhede wat pas by die boodskap van 
die kruis as God se onsin en swakheid volgens die wysheid van die wêreld (1:18-25).

Deur Paulus se woord en lewe het Christus hulle geroep en afgesonder as die gemeente van God in Korinte (vgl 1:2). Hulle was ook oorwegend sonder aansien of betekenis in die samelewing (1:26-31). Paulus is nie 'n indrukwekkende vader wat sy kinders lei om sosiaal belangrike mense te word nie. Hulle roem oor status en sukses is juis die rede vir die onenighede in die gemeente wat Paulus probeer besweer. As 'n vader moet hy egter sy geliefde kinders teregwys, juis vir "sommige" van die menigte leermeesters ( $p$ a i da g wg ou; , 4:15) wat hulle self verhef het toe dit lyk of Paulus nie terugkom nie, en hulle hoogmoedig op ander begin neersien het (4:18-19). Hy wil soos ' $n$ vader liefdevol en vriendelik na hulle toe kom. Maar as daar nie op sy brief en Timoteus se besoek positief gereageer word nie, sal hy die roede moet gebruik om hulle op die regte pad terug te kry (LXX Spr 10:13 r abdw/ t up t ei ahdra akardion). Die metafoor van die vader met 'n slaanding verwys na die noodsaaklikheid van teregwysing in die gemeente (vgl qa r r w' reguit praat, in 2 Kor 10:2). Die onsedelikheid wat in 5:1-5 beskryf word, noodsaak juis so 'n teregwysing.

Aan die begin van sy bediening het Paulus ${ }^{4}$ hulle met melk gevoed omdat hulle nog wêrelds was, soos kindertjies in hulle geloof in Christus wat nog nie vaste kos kon verteer nie. Hy is teleurgesteld dat hulle nog steeds wêrelds is met hulle onderlinge jaloesie en twis, en nou nog nie vaste kos kan verteer nie (3:1-3). So roep hierdie vader sy broers in 14:20 op om nie langer in hulle denke kinders te wees nie; wel onvolwasse in die slegte dinge, maar volwasse in hulle denke (vgl ook 13:11).

Volgens 1 Korintiërs 4:14-21 kom Paulus se beeld van sy vaderskap egter nie primêr uit die Griekse filosofie of die Romeinse tradisie of sy Joodse erfgoed nie, maar vanuit sy geloof in Christus. Sy geestelike vaderskap volg vir hom vanuit 'n lewe in gemeenskap met Christus wat deur hom as vader

\footnotetext{
${ }^{4}$ Lassen (1991) suggereer dat Paulus aan die einde van sy beskrywing van sy taak in Korinte (1:10-4:21) die beeld gebruik van die vader as verwekker van die gemeente. Daarmee sou hy sy gesag oor die gemeente bevestig. Toe Paulus in Korinte aangekom het, was die ou Griekse demokratiese ideale reeds vervang deur die Romeinse vaderbeeld vir die keiser as die pater patriae op hulle geld, inskripsies, en in die keiserkultus. So is die gesag van die keiser in die provinsie bevestig. Lassen skilder die honderdjarige Romeinse invloed op Korinte as reliëf vir Paulus se gebruik van die vaderbeeld. Sy word hierin gevolg deur Horrell (1996:197). Vergelyk ook Winter (1994:1168) wat verwys na die Korintiese inskripsies wat na Julius Caesar verwys as hulle stigtervader. Myrick (1996) erken ooreenstemmings tussen Paulus se vaderbeeld, die Hellenistiese moraal filosofie en die Romeinse tradisie, maar beklemtoon die moontlikheid dat Paulus sy beeld as vader van die gemeente uit sy Joodse erfenis ontvang het, waar 'n pastorale leier beskou is as ' $n$ vader wat sy kinders lei en versorg, en waar die leiding en versorging ook konfrontering in liefde insluit (vgl Spr 3:12). Williams (1999:58) sien in die vader-kind-beeld juis Paulus se groot toegeneentheid teenoor sy bekeerlinge en sy aanspraak op hulle toegeneentheid. As die toegeneentheid ontbreek, soos vir 'n tyd lank by die Korintiërs, maak Paulus nogtans aanspraak op hulle gehoorsaamheid maar nie op sy gesagsposisie nie.
} 
van die gemeente werk. Drie keer skryf hy ej $\mathrm{C}$ ris $\mathrm{t}$ w/in $4: 15,17$. As Christene het hulle nie baie vaders nie, slegs vir Paulus wat hulle gemeente gestig het (4:15a). Sy vaderskap vloei voort uit sy stigting van die gemeente deur hulle tot geloof in Christus te lei, deur die evangelie wat Paulus in gemeenskap met Christus aan hulle verkondig het en wat deur Christus se werking deur hulle aanvaar is (4:15b). Dit bring mee dat die vader se lewenswandel saam met Christus 'n voorbeeld is wat gevolg is en nagevolg moet word (4:17). Dié soort vaderskap behels 'n liefdevolle (t ek na mou a g a pht a), nederige en vriendelike gesindheid (ej a gaph/p neuma t i vt e pra ue ht $0 \sim 4: 14,16,21$ ) soos Christus (2 Kor 10:1:dia; t h $\sim$ pra ue ht $0 \sim$ kai; ej ieikei $~ t$ ou'C rist ou), voortgaande onderrig in die regte gedrag en geloof (4:14 nouqet $w$ 'praesens), en ernstige teregwysing as dit nodig word (4:16 parakal ew, 4:21 ej rabdw). Met sy kruisboodskap (2:2) roep Paulus die gemeente om soos hy te lewe in ooreenstemming met die gekruisigde Christus (4:9-14; vgl Eks 34:6-7; Ps 99-98:8 vir God se liefde, genade en vergifnis, maar wat niemand sonder meer vryspreek nie).

Uit sy opdrag aan die gemeente in 5:3-5 blyk dit dat die vader en stigter van die gemeente namens ons Here Jesus reeds besluit het ( $\mathrm{W} h \mathrm{~h}$ kekr i na) wat gedoen moet word met die lidmaat wat in bloedskande lewe. As verteenwoordiger van ons Here het Paulus die besluit geneem (5:3b, 4a; Fee 1993:206-208 op gesag van). Deur die werking van die Heilige Gees is Paulus se gees ook teenwoordig in die gemeente se samekoms, moontlik deur voorlees van hierdie brief waardeur hulle sy gedagtes oor die saak leer ken. Die samekoms van die gemeente en Paulus se gees of gedagtes sal dan die betrokke lidmaat oorgee aan die Satan, hom uit die gemeente verwyder (5:2), met die krag van ons Here Jesus. Die krag van die Here van die kerk dra en bepaal die besluit en optrede van die gemeente. In 1:18 word die boodskap van die kruis beskryf as die krag van God om te red. In 5:5 voorsien Paulus dat die krag van die Here die sondaar sal red. Paulus sien sy vaderskap van die gemeente as verteenwoordiger van Jesus wat deur sy en die gemeente se gesamentlike besluit werk. Hulle is verteenwoordigers van die gekruisigde Christus wat in heerlikheid kom (5:5; ons paaslam 5:7)

Die beskrywing van Paulus se lewenswyse in hoofstuk 9 is die voorbeeld wat hy vir die sterkes voorhou om van hulle regte af te sien ter wille van die swakker broers ten opsigte van die eet van vleis wat aan die afgode geoffer is (hoofstukke 8 en 10; vgl 8:13 en 10:33). Hy het van sy reg op lewensonderhoud afgesien om geen hindernis in die weg van die evangelie van Christus te lê nie (9:12). Hy het met sy eie hande gewerk, soos die armes, om nie die swakkes te belas nie (9:22; Horrell 1995:210-216). So word die argument afgesluit met die oproep om sy voorbeeld te volg, soos hy die 
voorbeeld van Christus volg (11:1). Hy is vader van die gemeente wat hulle met sy voorbeeld van liefde en nederigheid lei, soos Christus vir ons voorgeleef het (vgl 11:23-26 vir Jesus se oorgawe van sy liggaam vir ons). Hy is allermins 'n vader wat sy gesag oor ander met geweld wil handhaaf, en verwag geensins slaafse onderdanigheid aan hom nie. Op voetspoor van Christus wil hy dienaar van sy kinders se heil wees.

\section{4. 'N WAARSKUWENDE VADERSKAP}

In hoofstukke 8-10 wys Paulus dat die eet van vleis wat aan afgode geoffer is, by die Korintiese maaltye in die tempels van hulle afgode, onversoenbaar is met die diens van God in die gemeente van Christus, omdat dit diens aan die afgode en aan die duiwel is.

Die gemeente beleef reeds die einde van die tye omdat ons verbind is aan Christus wat gekom het. Daarom kan gelowiges terugkyk na die Israeliete in die woestyn as "ons vaders" (vgl Neh 9:16; Ps 78:12) en na wat met hulle gebeur het as "voorbeelde" (t up oi 10:6; t up i kw 10:11) wat opgeskryf is om ons te waarsku (nouges i a = teregwysing, 10:11). Daarmee waarsku Paulus die selfversekerdes in Korinte dat hulle deelname aan die sakramente nie vir hulle vrywaar teen die gevolge van hulle deelname aan die offerfeeste van die afgode nie (10:1-13). Terwyl Paulus se geestelike vaderskap 'n voorbeeld is wat nagevolg moet word, skilder hy daardie vaders se optrede en God se oordeel oor hulle om die gemeente te waarsku om nie hulle vaderskap na te volg nie.

Die gemeente in Korinte het hoofsaaklik uit gelowiges uit die heidendom bestaan $(6: 10-11 ; 8: 7 ; 12: 2)$. Paulus beskou hulle egter as die gemeente van God in Korinte wat aan Hom behoort; vir Hom afgesonder is (1:2), soos Israel was. Met "ons vaders" beklemtoon Paulus die verband tussen God se verhouding met Israel en met die gemeente in Korinte. Hy verduidelik dié verband met die doop en die nagmaal. Die Korintiërs se nuwe lewe in gemeenskap met Christus het met hulle doop begin (vgl 1:13-17). So het Israel se verlossing uit Egipte begin met 'n soort doop deur water heen, met die wolk bokant hulle en die see aan weerskante (10:1-2). Die Korintiërs word geestelik gevoed deur die nagmaal se wyn en brood as die gemeenskap met die bloed en liggaam van Christus (10:16). Israel se geestelike voedsel was die manna wat God daagliks geskenk het, en hulle geestelike drank die water uit die rots Christus (10:4). Maar, ten spyte daarvan dat God Israel verlos en versorg het deur Christus, soos Hy die Korintiërs deur Christus verlos het en versorg, was God met die meeste van "ons vaders" nie tevrede nie en is hulle lyke verstrooi oor die woestyn as gevolg van hulle sondige begeertes (10:5). Paulus verskaf vier voorbeelde van Israel se sondige 
begeertes waarin hulle vaderskap van die Korintiese gemeente ernstige waarskuwingsligte laat flikker oor God se houding oor die Korintiërs se optrede in 10:7, 8, 9, 10.

Met die metafoor van Israel se vaderskap teenoor die gemeente teken Paulus die voortskrydende ontwikkeling van God se verhouding met sy eie mense deur die bemiddeling van Christus in die Ou-Testamentiese bedeling en in die Nuwe-Testamentiese gemeente as volk van God. Vanuit Christus en die nuwe volk van God word die belewenisse van Israel in die woestyn as voorbeelde aangehaal. Israel se afgodsdiens, ontug, uittarting en verset teen God in die woestyn beskryf voorbeelde van vaders wat juis nié deur die gemeente nagevolg moet word nie, en wat lei tot die oproep "vlug van die afgodsdiens af weg!" (10:14).

\section{GOD AS DIE VADER MAAK LEWEND}

In hoofstuk 15 weerlê Paulus die Korintiërs se ontkenning van die opwekking van die liggaam uit die dood. Die Korintiërs het wel geglo dat God vir Christus opgewek het (vgl 15:11). Maar hulle het 'n geestelike verlossing gesoek vir hulle onsterflike siele, wat uiteindelik van die liggaam ontslae sou wees. Omdat God egter vir Christus uit die dood opgewek het, verkondig Paulus dat Hy die dooies (oijnek roi y sal opwek en dié wat by die laaste trompet nog lewe, sal verander. Hierdie verganklike en sterflike liggame sal beklee word met onverganklikheid en onsterflikheid (15:51-53; 6:14).

Die opwekking van Christus het die gelowiges se bestaan in die hede en vir die ewigheid bepaal (15:19). Hy is die eersteling uit dié wat ontslaap het, die waarborg dat God dié wat aan Christus behoort sal opwek by Christus se koms $(15: 20,23)$. God het alles aan Christus se heerskappy onderwerp (27; vgl Ps 8:6). Van sy opwekking en hemelvaart af heers Christus as koning totdat Hy al die vyande aan Hom onderwerp het (v 25; vgl Ps 110:1). God het die gelowiges se opwekking verbind aan Christus as die eersteling se opwekking (vgl v 20; ej t w/C rist w/z wop oihs ont a i, v 22). Christus vernietig ook die dood as die laaste vyand deur die opwekking van die gelowiges (26).

Die einddoel (t evo , v 24) van Christus se vernietiging van elke heerser (aj chy, elke gesag (ejous i a) elke maghebber (duma mi ) waarby die dood ingesluit is, word bereik met die opwekking van die dooies. Dan dra Christus die heerskappy wat God aan Hom opgedra het aan God die Vader oor (t w/qew/ka i vp a t r i w 24). Die oordrag word in vers 28 beskryf as "Wanneer (God) alles aan Hom (die Seun) onderwerp het, dan sal die Seun self Hom onderwerp aan die een wat alles aan Hom onderwerp het (God), so sal God alles wees vir alles (p a nt a ej pas' in) wat sy Vaderlike heerskappy 
oor alles direk uitoefen. So lyk die verlossingswerk van Christus. Hy kom God se wil oral en op elke wyse uitvoer. God is die Vader wat alles geskep het, en die einddoel van die hele skepping. Hy gee die koningskap aan die Seun, onderwerp al sy vyande aan die Seun, en aan die einde dra die Seun die koningskap aan Hom oor. Die noue verband tussen die Vader en die Seun impliseer dat God die Vader van Christus is aan wie God alles onderwerp het (vgl Ps 8:6; 110:1).

God die Vader en Christus die Seun werk saam om mense lewendig te maak (22b). Dit is duidelik dat God die Vader (v 24b) sy doel in die geskiedenis uitwerk deur die Seun (v 28b) en dat die Seun Homself ten volle onderwerp aan die Vader se doel met Hom en met die skepping. Die onderwerping van Christus aan God (vgl 3:23; 11:3) staan in skrille kontras met die Korintiërs wat hulleself verhef (vgl 4:6-8). Die Vader inisieer die hele aksie (v 27a), wek Christus op uit die dood (23b), plaas alles onder Christus se heerskappy (27a), sit die aksie voort deur Christus ( $v 22 b)$, bepaal die einde (24a), voltooi die aksie deur Christus (v 28a), wek by Christus se koms diegene op wat aan Christus behoort (23c), en die Vader is die einddoel van die hele lewend-makende aksie (v 24b, 28c). "... sodat God alles sal wees ...": Hy is die enigste doel en rede van die lewe vir alles (Wolf 1982:184). "... in alles": Hy oefen weer sy hele heerskappy direk oor alles uit (Conzelmann 1969:326-7). En dit is die heerskappy van sy liefde soos die Seun dit aan die kruis geopenbaar het (vgl 2:2; 11:23-26; 13:13).

God is die Skepper-Vader uit wie alles kom en aan wie alles oorgegee word. As gekruisigde (2:2) kom die Seun met liefde wys hoe die Vader werklik is, en leer hoe om God as die Vader lief te hê en te eer. So oorwin die Seun die vyandelike magte. Die Vader maak elkeen in Christus lewend by Christus se koms in heerlikheid. Dan sal God as liefdevolle Vader regeer oor sy skepping waaroor Hy steeds verantwoordelik bly.

\section{DIE ENIGSTE WARE GOD AS DIÉ VADER: SKEPPER, HERSKEPPER, EINDDOEL}

Volke, waaronder die Grieke, het hulle hoofgod as vader aanbid (vgl Homerus se pat hr Z eu৮ of Z eu 'p at er, Od 4:341; II 1:503), en hom as die skepper en verwekker van lewe beskou; onder minoïese invloed word hy vader van die gode genoem (Od 1:28; /l 1:544; Epict, Diss 1:3:1; vgl Schrenk 1954:951953); hy is ook vader van vaders (Epict, Diss 3:11:5). Die Grieke se beskouing oor vaderskap stem ooreen met hulle denke oor hulle gode as vaders wat oor hulle waak en hulle beskerm (vgl Epict, Diss 1:12:8; 3:22:82; 3:24:3, 16; 4:1:104; Schrenk 1954:954:11). Hulle belewenis van die menslike vader met 
al sy gebreke het egter ook hulle voorstelling van hulle gode as vaders met gebreke sterk beïnvloed (Schrenk 1954:953:6).

Met 0 Jp at $h r$ as byvoeging by eif qeo $r$ in 8:6 verwys Paulus spesifiek na dié Vader, die enigste ware God vir die gelowiges, teenoor die afgode van die heidene (vgl Deut 10:17). Die Vader word beskryf as die bron van die ganse skepping (daarom is die skepping en alle voedsel goed; vgl Conzelmann 1969:171), en die einddoel van ons lewe (ejx oult a; $p$ a nt a ka i; hmei $\sim$ eij a uf. on). Daarby word ingesluit dat Hy die bron is van ons verlossing (vgl 1:4), en die einddoel van die hele skepping (vgl 15:28). Maar God word spesifiek as die bestemming van die gelowiges aangedui (ons hele bestaan is vir sy doeleindes; Fee 1993:375). Dit doen Hy deur die enigste ware Here, Jesus Christus, deur wie God alles skep en ons verlos (di joult a ; pant a kai; hmei $\sim$ di ja ut ou). Aangesien Hy deur Jesus Christus alles skep en ons herskep, behels God se Vaderskap dat Hy die eintlike bron of inisieerder van die skepping en van ons herskepping is. Dat Christus ook die skeppingsmiddelaar is, verbind Hom op 'n unieke wyse aan God as sy Vader. As die God wat ook ons verlossing inisieer, is Hy op 'n nuwe manier ons Vader vir wie ons lewe, en tot wie ons deur Christus in gebed kan nader (vgl 1:4). Hy werk ons verlossing ook verder uit, deur Christus. In 12:6 sê Paulus: "dit is dieselfde God wat alles in almal tot stand bring." Paulus se beeld van God as die Vader kom nie uit sy belewenis van menslike vaders soos die heidene nie, maar primêr uit sy belewenis van God se verlossing deur Jesus Christus (vgl 2:1-2; t 0; mus t hri on t ou ' $\mathrm{Q}$ eou', wat niks anders is as die gekruisigde Jesus Christus nie, die krag en wysheid van God; 1:24).

Teenoor die baie kuri o 0 wat as gode en verlossers vereer word (veral in die misteriegodsdienste; Fee1993:373), is Jesus Christus die enigste ware Here aan wie ons behoort en van wie ons afhanklik is (vgl Foerster 1938:1090, 30-35; dit gee aan ons die vryheid om nie meer met die magte te reken nie, Conzelmann 1969:172).

Paulus stem saam met die Griekse Christene in Korinte dat daar slegs één God is wat alles gemaak het, en ons daarom alles mag eet (8:4). Die "sterk" Korintiërs gebruik die kennis egter om vreesloos deel te neem aan die feeste van die afgode wat dan nie sou bestaan nie. Die "sogenaamde" gode bepaal egter die siening en lewenswyse van die heidene en beïnvloed die Christene met ' $n$ "swak gewete" $(8: 5,7)$, en verlei die "sterk" Christene tot gemeenskap met duiwels by dié feeste (10:20). Die wete dat daar slegs één God is wat as Vader ons verlossing geïnisieer het en die einddoel van ons lewe is, behoort die gelowiges juis te lei om hulle hele lewe daarop te rig om God lief te hê (8:3; hmei $\sim$ eij a uf on, 8:6) en sy doel met ons lewe te bereik. Die Vader het ons juis geroep om in gemeenskap met sy Seun Jesus Christus 
te lewe (1:9) en Hom op dié wyse lief te hê (8:3). Daarom moet ons eerder die swakkes deur die liefde opbou in hulle geloof (8:1) as om struikelblokke te wees wat hulle laat val en verlore laat gaan, en so teen Christus sondig (8:1112). Met die beeld van die huisgesin verduidelik Paulus dat God wat ons Vader is deur ons verbondenheid aan sy Seun, gelowiges aan mekaar verbind as broers en susters wat mekaar moet liefhê soos die Vader ons lief het tot die uiterste selfverloëning van die kruisdood van die Seun. "Daarom, as ek deur wat ek eet, my broer laat struikel, sal ek nooit weer vleis eet nie" (8:13; a jel f o $\forall / a$ del f o i word 39 keer en a jel f h v2 keer in 1 Kor gebruik as aanduiding van medegelowiges).

Die één God is die Vader van die skepping en van ons herskepping. Hy skep en herskep deur Christus. God as die Vader is ook die sin en einddoel van ons lewe, vir wie ons moet liefhê en vir sy hele gesin, gelowiges wat ons broers en susters word. Dit word slegs moontlik deur ons verbondenheid aan Christus.

\section{GOD AS ONS VADER}

Die seëngroet van genade en vrede som God se handeling teenoor die mens op (1 Kor 1:3). As "ons Vader" (p a t r $0 ; \sim$ h hnwh̀) gee Hy Homself aan ons in die genadedaad van die Here Jesus Christus, eenmalig aan die kruis en dag na dag, vandaar Paulus se seëngroet. Met die een voorsetsel (a p oy om ons Vader en Here as die bron van die seën aan te dui, wys Paulus op hulle noue samewerking in harmonie met mekaar. Genade verwys na God as die genadige Vader wat die oorsprong en bron van ons hele Christelike lewe is (vgl "deur sy genade is ek wat ek is ..." in 15:10; Barrett 1991:35). Deur sy kruisdood (eś t a ur wmenon, 2:2) het Christus ons vir God afgesonder om aan Hom te behoort (hgias menoi ) en ons geroep het om vir God te lewe (k| ht oi z a gioi , 1:2, 24). God word Vader genoem omdat Hy in Christus se koms na die aarde toe Hom as Vader geopenbaar het aan die mense wat die Naam van Jesus Christus aanroep (1:2); nie as die Vader van alle mense deur geboorte en skepping nie. God is in dié sin slegs die Vader van die mense vir wie Jesus Christus die Here is (Schrage 1991:107). In sy genade en vrede lewe elke gelowige.

Die danksegging (1:4-9) brei uit op die c a vi en eij $h$ hh van God ons Vader en van die Here Jesus Christus. C a vi word in 1:4 verduidelik as God se vrye geskenk ( $h$ /dogei s $h$ /... ej $C$ ris t w/ J h s ouly aan die gemeente. In sy genade het God Homself bekend gemaak in die kruisdood van Christus vir die redding van die wat glo. In sy genade het God Homself in Christus gegee aan die mense wat Hy geroep het (1:18, 21, 23, 24). Dunn (1975:202) 
beklemtoon dat genade vir Paulus nie 'n gesindheid of geneentheid van God aandui nie, maar eerder die hele genadige daad van God. Volgens 15:10 werk God in sy genade ook voort in Paulus se daaglikse wilsbesluite en optrede (vgl ook 3:10). In 1:5 verduidelik hy verder wat met die genade bedoel word ( 0 i ): dat God (passivum divinum) die gelowiges in die nouste verbinding met Christus gebring het (ej a uf. wi) om hulle op alle terreine van die lewe te verryk (ej $p$ ant $i$; ej I out i g qht e, vgl die beklemtoning in 1:7; mh; us ter eis̀ qa i ej mhdeni; car i s mat $i$; Weiss1970:7). Met al die gawes, en in die besonder die gawes van die woord en kennis, wat God in oorvloed deur Christus aan die Korintiese gemeente gee het, het God Paulus se getuienis oor Christus, oor sy dood en opstanding (vgl 15:1-11), in die gemeente gevestig (epeba i wqh, 1:6, 7). Deur God se genade bly die gemeente ook vol verwagting uitsien na die dag wanneer ons Here Jesus Christus Hom aan ons sal openbaar (1:7). God is ' $n$ Vader wat aktief by sy kinders betrokke is deur sy Gees wat ons van Hom ontvang het (2:12).

E ij hah word in die LXX gebruik om $\mathrm{m} / \mathrm{l}$; ; weer te gee (vgl bv Jes 52:7; Von Rad 1935:400-405; Foerster 1935:405), en het so in die Nuwe Testament 'n betekenisverruiming van die Griekse woord gekry wat die heelwees, welwese en heil van die mens en sy verhoudings omsluit (Schrage 1991:106). Dit is die vrug van God se verlossingswerk. In 1:8,9 word twee opmerkings gemaak wat goedskiks uitbrei op ei j h nh wat die Vader en Christus in die seëngroet meedeel: 1:8 verwys na die vrede van die gemeente wat voortgaan tot op die oordeelsdag; 1:9 veral na die vrede van die gemeente wat reeds in die hede begin. In 1:8 spreek Paulus sy vertroue uit dat God se vaderlike sorg sy kinders ook tot op die end sal laat vasstaan in hulle getuienis oor Christus, sodat daar geen aanklag teen hulle sal wees op die dag dat ons Here Jesus Christus kom nie. Op grond van Christus se sterwe en opstanding het God hulle nou reeds vrygespreek (a jeg kl ht $0 \sim$ = onskuldig; Grundmann 1933:358-359), en God sal sorg dat hulle sal bly lewe in 'n vredesverbond met hulle (vgl Jes 54:10). In 1:9 getuig Paulus van God se trou. So is ons Vader! God sal geduldig voortgaan om te voltooi wat God begin doen het toe God ons geroep het (Pop 1965:19). God het ons geroep om verenig te lewe met God se Seun, Christus Jesus, as ons Here. God sluit ons in by die heil wat God se Seun vir ons berei het, en onder sy seggenskap oor ons lewe. So lyk die vrede wat ons Vader en sy Seun daagliks aan ons skenk tot in die ewigheid, vrede tussen die Vader en sy kinders deur die werk van Jesus Christus as die gekruisigde (2:2), wie se Gees ons ontvang het (2:16).

\section{OPSOMMENDE OPMERKINGS}

Die Jood Paulus se siening van die God wat met Israel 'n verbond gesluit het (vgl 10:1, 18; 11:25) het radikaal verander deur sy Christologie (1:22-25). Hy 
ken God nou as ons genadige Vader vir wie hy liefhet (1:3; 8:3). Dit het gebeur deur sy ontmoeting en denke oor ons Here Jesus Christus wat na sy hemelvaart aan hom verskyn het $(1: 3,9,10 ; 9: 1 ; 15: 7)$. Die Vader het sy Seun vir ons sonde laat kruisig $(2: 2 ; 5: 7 ; 15: 3)$, en Hom uit die dood opgewek om ons uit sonde en die dood te red $(15: 4,15,20)$ sodat ons, verenig met sy Seun, Christus Jesus, vir God sal lewe (1:9).

Vir Paulus is God die Skepper-Vader uit wie alles kom en aan wie alles oorgegee word. In sy goedheid het Hy sy Seun gestuur om aan 'n kruis te kom sterf om dié te red wat in sy Seun glo. So kom die Seun met liefde wys hoe die Vader werklik is. Hy leer ons hoe om God as ons Vader lief te hê en te eer. Op dié wyse laat God die Seun as koning heers. Met sy liefdesoffer vernietig God se Seun alle bose magte, sy vyande en die dood. Die Vader maak dié wat in Christus is, lewend by Christus se koms in heerlikheid. Dan sal God as liefdevolle Vader regeer oor die hele skepping (15:22-28; 1:21-25).

Sy Griekse lesers het vroeër baie gode en here geken en vereer. Vir die gelowiges in Korinte bevestig Paulus dat daar slegs één God is. God is die Vader wat alles deur die een Here, Jesus Christus, geskep het en onderhou. God die Vader is ook die sin en einddoel van ons lewe, vir wie ons moet liefhê en vir God se hele gesin, die gelowiges wat ons broers en susters word. Dit word slegs moontlik deur ons verbondenheid aan Christus. (8:4-6; 1:9, 10). Daarin word ons gelei en begelei deur God se Gees (2:4, 10-16).

In die nuwe bedeling van die Here is die onderlinge verantwoordelikheid en wedersydse afhanklikheid van man en vrou God se wil $(11: 11,12$, vgl hoofstuk 7). Dit stem ooreen met die Ou-Testamentiese wet wat eer vra vir vader sowel as moeder (Eks 20:12). Vandaar ook Paulus se veroordeling van die lidmaat wat sy vader onteer deur met sy stiefmoeder in 'n seksuele verhouding te lewe $(5: 1)$.

In die nuwe verbond wat Christus gebring het, is die gemeente die volk van God. Paulus hou die volk van God in die Ou-Testamentiese bedeling voor as 'n voorbeeld om die gemeente te waarsku teen afgodsdiens. Hy noem Israel in die woestyn "ons voorvaders"(10:1). Dit is 'n metafoor waarmee hy die voortskrydende ontwikkeling van God se verhouding met sy eie mense tipeer. So is gelowiges deur die eeue verantwoordelik teenoor die nageslagte van God se kinders.

As stigter van die gemeente is Paulus vader van die gemeente wat hulle met sy voorbeeld van liefde en nederigheid lei, soos Christus vir ons voorgeleef het $(4: 9-17,21 ; 2: 16)$. Hy wil nie sy gesag met geweld handhaaf nie en verwag nie slaafse onderdanigheid aan hom nie. Op voetspoor van Christus wil hy dienaar van sy kinders se heil wees $(3: 9,22 ; 4: 9-17,21 ; 2: 16)$. Hy bly vir hulle verantwoordelik teenoor God. 


\section{Literatuurverwysings}

Aristoteles. Politica. Loeb.

Barrett C K 1971. A commentary on the first epistle to the Corinthians. London: Black.

Blundell, S 1995. Women in ancient Greece. Cambridge: Harvard University Press. Cicero. Pro Cluenti. Loeb.

Conzelmann, H 1969. Der erste Brief an die Korinther. Göttingen: Vandenhoeck. (KEK V.)

Csillag, P 1976. The Augustan laws on family relations, tr by J Decsényi. Budapest: Akadémiai Kiadó.

Dio Cassius. Historia Romana. Loeb.

Dunn, J D G 1975. Jesus and the Spirit: A study of the religious and charismatic experience of Jesus and the first Christians as reflected in the New Testament. London: SCM Press.

Durham, J I 1987. Exodus. Waco, TX: Word Books. (WBC 3.)

Epictetus. Dissertationes. Loeb.

Fantham, E, Foley, H P, Kampen N B, Pomeroy, S B \& Shapiro, H A 1994. Women in the classical world. New York: Oxford.

Fee, G D 1993. The first epistle to the Corinthians. Grand Rapids, MI: WB Eerdmans. (NICNT.)

Findlay, G G 1951. St Paul's first epistle to the Corinthians. Grand Rapids, MI: Eerdmans. (ExpGT.)

Foerster, W 1935 s v. Eijh nh. ThWBNT II.

Foerster, W 1938 s v. kuri o . ThWBNT III.

Gaius. Gaii institutionem iuris civilis commentarii quattor, tr by E Poste, 3rd ed 1890. Oxford: Clarendon.

Grundmann, W $1931 \mathrm{~s}$ v. a jeg kl ht 0 . ThWBNT I.

Homerus. Ilias. 1952. Leaf, W \& Bayfield, M A (eds). London: Macmillan.

Homerus. Odusseia. 1947. Stanford, (ed). London: Macmillan.

Horrell, D G 1996. The social ethos of the Corinthian correspondence: Interests and ideology from 1 Corinthians to 1 Clement. Edinburgh: T\&T Clark.

Jolowicz, H F \& Nicholas, B 1972. Historical introduction to the study of Roman law. 3rd ed. Cambridge: University Press.

Josephus. Antiquitates. Loeb 1926.

Josephus. Contra Apionem. Loeb 1926.

Josephus. Complete works of Flavius Josephus, Whiston, W 1960. Grand Rapids. Ml: Kregel.

Lassen, E M 1991. The use of the father image in imperial propaganda and 1 Corinthians 4:14-21. Tyndale Bul 42(1), 127-136.

Louw, J P \& Nida, E A 1988. Greek-English lexicon of the New Testament based on semantic domains. United Bible Societies.

Malan, F S 1985. Die hoed en die vrou in die erediens volgens 1 Korintiërs 11:2-16. Theologia Viatorum, 13(1), 57-69.

Marindin 1949. A smaller classical dictionary of biography, mythology, and geography. London: J Murray.

Martialis. Epigrammae. Loeb. 
Mitteis, L 1963 (1891). Reichsrecht und Volksrecht in den östlichen Provinzen des römischen Kaiserreichs: Mit Beiträgen zur Kenntnis des Griechischen Rechts und der spätromischen Rechtsentwicklung. Hildersheim: G Olms.

Myrick, A A 1996. "Father" imagery in 2 Corinthians 1-9 and Jewish paternal tradition. Tyndale Bulletin 47(1), 163-171.

Ortolan, 1896. The history of Roman law, tr by I T Pritchard \& D Nasmith, 2 ed by $\mathrm{J}$ Cutler. Histoire de la législation Romaine et généralisation du droit. London: Butterworth.

Perriman, A C 1994. The head of a woman: The meaning of kef a l hvin 1 Cor 11:3. JST 45, 602-622.

Philo. De Specialibus Legibus. Loeb.

Plato. Cratylus. Loeb.

Plato. Gorgias. Loeb.

Plato. Leges. Loeb.

Pop, F J 1965. De eerste brief van Paulus aan de Corinthiërs. Nijkerk: Callenbach. (PNT.)

Saller, R P 1998. Symbols of gender and status in the Roman household, in Murnaghan, S \& Joshel, S R (eds) Women and slaves in Greco-Roman culture. London: Routledge.

Schrage, W 1988. The ethics of the New Testament, tr by D E Green. Philadelphia, PA: Fortress.

Schrage, W 1991. Der erste Brief an die Korinther (1 Kor 1, 1-6, 11). Neukirchener: Benziger. (EKK VII/1.)

Schrage, W 1995. Der erste Brief an die Korinther (1 Kor 6, 12-11, 16). Neukirchener: Benziger. (EKK VII/2.)

Schrenk, G 1954 s v. pat hr. ThWBNT V.

Seneca. De Beneficiis. Loeb.

Strack, H L \& Billerbeck, P 1926. Kommentar zum Neuen Testament aus Talmud und Midrasch. München: $\mathrm{C} \mathrm{H}$ Beck.

Tacitus. Annales: Ab excessu divi Augusti. Loeb.

The Revised English Bible with the Apocrypha 1989. Oxford: Oxford University Press.

Von Rad, G 1935 s v. m/l v; ThWBNT II.

Von Rad, G 1966. Deuteronomy: A commentary. London: SCM Press.

Weiss, J 1970. Der erste Korintherbrief. Göttingen: Vandenhoeck \& Ruprecht. (KEK.) Wendland, H D 1968. Die Briefe an die Korinther. Göttingen: Vandenhoeck. (NTD 7.) Williams, D J 1999. Paul's metaphors: Their context and character. Massachusetts, MA: Hendrickson.

Winter, B 1994. 1 Corinthians, in New Bible Commentary, 1161-1187, edited by D A Carson et al. Leicester: Inter-Varsity.

Wolff, C 1982. Der erste Brief des Paulus an die Korinther, Zweiter Teil. Berlin: Evangelische. (Th HNT 7/2.)

Yancey P [1995] 2002. Finding God in unexpected places. London: Hodder \& Stoughton. 